
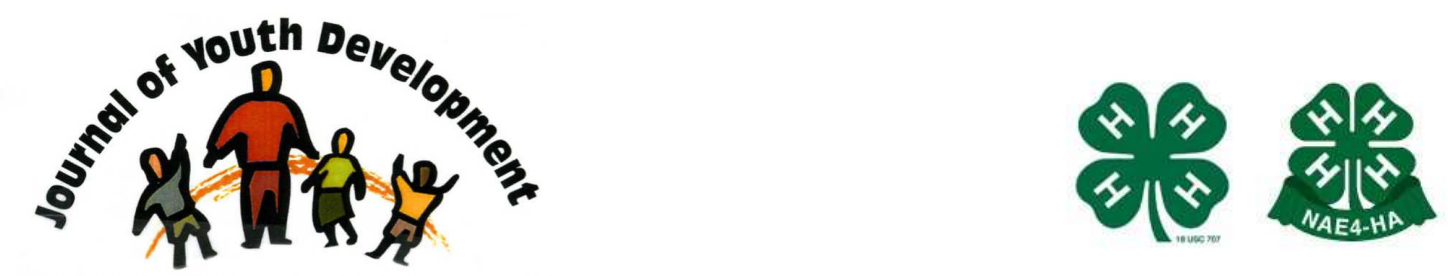

Bridging Research \& Practice

\title{
Examining the Use of Social Media among Four-H Alumni in Louisiana
}

Kali B. Zammit

4-H Youth and Family Development

Louisiana State University AgCenter

Raceland, LA

kzammit@agcenter.Isu.edu 


\title{
JOURNAL OF YOUTH DEVELOPMENT \\ bridging research and practice

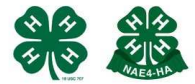

Bridging Research \& Practice

Volume 9, Number 2, Summer 2014

Article 140902RS003

\section{Examining the Use of Social Media among Four-H Alumni in Louisiana}

\author{
Kali B. Zammit \\ Louisiana State University AgCenter
}

\begin{abstract}
The purpose of this study was to examine the use and determine the preferred method of social media among 4-H alumni in Louisiana. Based on a review of literature, communicating with youth through social media has become a major trend and necessity, especially among 4-H Youth Development and Cooperative Extension Service professionals. A 24-item instrument was developed and administered online to Louisiana 4-H alumni who received the 2011 Louisiana 4-H Senior Honor Cord and provided usable e-mails.

The overall preferred method of social media among Louisiana 4- $\mathrm{H}$ alumni was Facebook and text messaging. A majority of 4-H alumni use their smart phones or personal computers to utilize social media. Some of the primary reasons that 4-H alumni use social media are to communicate friends, view photographs, and become updated with current events. Overall, $100 \%$ of surveyed $4-\mathrm{H}$ alumni use some form of social media.
\end{abstract}

\section{Introduction}

According to a study conducted as part of the Pew Internet and American Life Project, "Some $93 \%$ of teens use the internet, and more of them than ever are treating it as a venue for social interaction - a place where they can share creations, tell stories, and interact with others" (Lenhart, Madden, Macgill, \& Smith, 2007, p. 2). As technology advances, teenage youth become familiar with a new method of communication, thus creating new technological trends. In an age where e-mail was once the epitome of technological communication techniques, emailing has become a second form of communication compared to texting, instant messaging, and social networking, especially among teens (Lenhart, Madden, Macgill, \& Smith, 2007). "Social networking is the number one activity on the web (eXtension Initiative, March 2010) and is replacing e-mail communication in the younger generations" (Robideau, \& Santl, 2011, p. 1). 
Social networking can be defined as "the use of Web sites or other online technologies to communicate with people and share information, resources, etc." (http://dictionary.reference. com). People are using forms of technology for social networking purposes. "Forms of electronic communication (as Web sites for social networking and microblogging) through which users create online communities to share information, ideas, personal messages, and other content (as videos)" is called social media (http://www.merriam-webster.com/dictionary). In other words, people use sources of social media to social network, or communicate online with other people. Although not all teens participate in social media websites, social networking has become part of an American teen culture in a short span of time (Boyd, 2008).

Throughout the past few years, people spend much of their time online using social media. There are various forms of social media, including blogs, Facebook, and Twitter, all of which are websites that can be used for social networking (Fuess, 2011). Most social networking sites have the option of creating a personalized, individual profile that may contain text, images, and videos for the public to view (Boyd, 2008). As Danah Boyd (2008) stated, "The social network site profile also contains comments from other members and a public list of the people that one identifies as Friends within the network" (p. 123). According to Pew Research Center (2010), "Nearly three quarters (72\%) of online 18-29 year olds use these sites - similar to the rate among teens - with $45 \%$ doing so on a typical day" ("Social Media," p. 18).

Knowing that social media has become a continuous trend among online users, organizations and businesses have joined the push to publicize and educate through social networking. "Companies and organizations are realizing that engaging in social media can allow for highly participative' interaction with customers and constituents which makes them feel more loyal and positive towards the company or organization performing the outreach (Culnan, 2010)" (Fuess, 2011, p. 7). As Fuess (2011) stated:

Particularly for non-profits, social media provide a new venue to marketing and outreach. Social media is a form of social marketing, on which many non-profits rely. Social marketing 'uses traditional marketing strategies to create social change by maximizing audience response' (Skelly, 2005, p. 7).

As a non-profit organization, the Cooperative Extension Service currently uses social media to provide research-based information to a wide variety of clientele in order to increase its outreach and impact (Fuess, 2011). The Cooperative Extension Service can utilize social media to "raise awareness about programs, help educate the public, attract new constituents, and enhance communication" (Fuess, 2011, p. 9).

The 4-H Youth Development Program is one of the major programming areas within the Cooperative Extension Service. The mission of the 4-H Youth Development Program is as follows: "4-H empowers youth to reach their full potential, working and learning in partnership with caring adults" (National 4-H Council, 2011, para. 1). Considering the mission of the 4-H program, 4-H Extension Agents have the responsibility of partnering and communicating with youth in order to develop their basic life skills. In an effort to address the needs of youth, 4-H agents need to stay abreast of the current trends of youth, including the use of social media. 4-H agents must be willing to learn and implement current communication plans with youth using technology (Robideau, \& Santl, 2011). As researchers Robideau and Santl (2011) suggested, "If programs do not keep up with online learning and the evolving communication tools, young people and their families will gravitate toward other programs that do provide 21st 
Century learning experiences" (p. 1). Therefore, understanding the current communication trends of youth is vital to conducting a successful youth development program.

\section{Purpose of the Study}

The purpose of the study was to examine the use and determine the preferred method in which 4-H alumni youth in Louisiana currently utilize social media. Adapting to the interests and trends of youth is critical in the youth development profession. By understanding the current technology trends of youth, 4-H agents can utilize social media according to the interests of youth in order to have a greater impact and disseminate educational information to a broader audience.

\section{Research Objectives}

1. To describe 4-H alumni youth affiliated with the 2011 Louisiana 4-H Youth Development Program based on general demographics including education, 4-H involvement, and ownership of social media devices.

2. To describe 4-H alumni youth affiliated with the 2011 Louisiana 4-H Youth Development Program on the following social media characteristics:

a) Types of social media currently used

b) Number of hours per day spent using social media

c) Primary source used for social media

d) Attraction to social media

e) Purpose of using social media

f) Use of selected social media

g) Perceived comfort in using social media

h) Ranking of preferred social media tool

i) Request for 4-H Facebook page features

3. To determine how Louisiana 4-H Alumni like to use social media as measured by the Zammit Social Media Questionnaire.

\section{Methodology}

\section{Purpose}

The purpose of this study is to examine the use and determine the preferred method in which 4-H alumni youth in Louisiana utilize social media. The results of this study will further implicate the best manner in which 4-H Extension agents should communicate with youth electronically to meet the demanding needs of youth.

\section{Population and Sample}

The target population of this study was 2011 4-H alumni in Louisiana. The accessible population was Louisiana 4-H alumni from 2011 who received the Louisiana 4-H Senior Honor Cord Award and whose e-mail addresses were provided. The 2011 Louisiana 4-H Senior Honor Cord Award was given to 319 recipients. Of the 319 Award recipients, the researcher obtained 172 e-mail addresses from contact information provided on the Louisiana 4-H Senior Honor Cord Award application. The researcher obtained an additional 16 e-mail addresses through Facebook contact. A total of 27 e-mail addresses were undeliverable or unusable. A final accessible population of $161 \mathrm{4}-\mathrm{H}$ alumni, whose e-mails were usable, was targeted for this study. This study was considered a census (100\% sample) of all 2011 Louisiana 4-H alumni who provided usable e-mail address as 2011 Louisiana 4-H Senior Honor Cord recipients. 


\section{Instrumentation}

The Zammit Social Media Questionnaire was created to serve as the instrument to examine the use of social media among 4-H alumni youth in Louisiana for the purposes of this study. The Zammit Social Media Questionnaire was developed to determine the frequency, sources, and reasoning in which $4-\mathrm{H}$ members utilize social media. The instrument includes a variety of questioning techniques, including multiple choice, multiple answer, open-ended, ranking, and Likert scale. The first section of the questionnaire focused on asking basic questions regarding use and preference of social media through multiple choice and multiple answer questions. The second section of the questionnaire focused on comfort and preference of social media activities using multiple answer, ranking, Likert scale, and open-ended questions. The third section of the questionnaire included demographic questions to describe the population in terms of age, gender, race or ethnicity, residence, 4-H membership, 4-H Junior Leadership Club members, education, and ownership of social media devices.

The Zammit Social Media Questionnaire was analyzed for reliability, and the Cronbach's Alpha score was .964. According to Hair (2006), any score over 0.9 is considered outstanding reliability.

\section{Data Collection}

The instrument used to collect research data was a questionnaire created through an online survey system (Zoomerang). This method of research is considered economical, convenient, and relative to the study. Using an online survey system aligns with the research objectives by using a form of social media (email) to distribute the questionnaire. Platform Louisiana 4-H alumni of 2011 who received the 2011 Louisiana 4-H Senior Honor Cord Award and provided a useable e-mail address were surveyed in this study.

Multiple contacts were made to increase the validity of the study (Dillman, 2007). The following process was used to collect data for the study:

1. Approximately one month prior to distributing the survey, the researcher sent a brief letter via e-mail to respondents regarding the study and requesting participation in the questionnaire. The researcher also contacted those participants who did not provide a usable e-mail address on their 2011 Louisiana 4-H Senior Honor Cord application through Facebook. The researcher sent a message to Facebook users regarding the study and requesting their participation in the questionnaire.

2. The Zammit Social Media Questionnaire was sent via e-mail approximately one month after the initial contact with respondents. The e-mail consisted of a cover letter to request participation in the study and to provide instructions for completing the questionnaire. In order to track student response, the researcher sent a message to Facebook participants requesting a usable e-mail address in which they would receive a URL-link to complete the questionnaire. Those Facebook users who responded with an e-mail address were immediately sent an e-mail consisting of the same cover letter to request participation in the study and to provide instructions for completing the questionnaire.

3. One week after sending the questionnaire, the researcher sent a friendly reminder to all non-respondents via e-mail with a URL-link to the survey.

4. One day after sending the reminder e-mail, all non-respondents were sent another reminder e-mail emphasizing the importance of their participation in the survey along with a URL-link to the questionnaire. 
5. One day after sending the second reminder e-mail, all non-respondents received a reminder e-mail requesting their participation in the survey. The researcher offered all respondents a chance to win one of three iTunes gift cards, which were mailed to the selected recipients. The e-mail also emphasized the overall importance of their participation and its relation to the 4-H program along with a URL-link leading to the questionnaire.

6. Two days after sending the third reminder, the researcher sent all non-respondents a final e-mail notification to complete the questionnaire. The researcher emphasized the importance of participation in the questionnaire and restated that all questionnaire respondents will have the chance to win one of three iTunes gift cards for their participation in the study.

Upon completion of data collection, the researcher analyzed the data by reading and reviewing each questionnaire. Answers to the questionnaire were grouped into themes that emerged from the data. Result findings were confirmed through thorough analysis of data.

A total of 32 respondents completed the web-based questionnaire. The final response count was 32 responses out of a possible 161 respondent (19.9\% response rate). The responses which are represented by response wave are presented in Table 1 , which can be found on the subsequent page.

\section{Population Demographics}

\section{Findings}

Objective one was to describe 4-H alumni youth affiliated with the 2011 Louisiana 4-H Youth Development Program basic demographic characteristics. The ages ranged from 18 to 20 years. The largest group of respondents indicated their age was 18 years $(n=13,48.2 \%)$. The second largest group indicated their age was 19 years $(n=12,44.4 \%)$. Majority of the respondents indicated their gender as female $(n=22,68.75 \%)$ while 10 respondents $(31.25 \%)$ indicated their gender as male. Majority of the respondents identified themselves as White $(n=24,77 \%)$. The second largest group identified themselves as Black or African American $(\underline{n}=6,20 \%)$. The respondents were also described in terms of their residence, or area in which they now reside. Majority of the respondents identified themselves as living on a farm or in a rural area $(n=14$, $43.75 \%)$. The second largest group identified themselves as living in a town with a population under 10,000 people $(n=8,25.00 \%)$.

Participants were asked to indicate the number of years in which they were a 4-H member. The number of years in which respondents were a $4-\mathrm{H}$ member ranged from 3 to 10 years. The largest group of respondents indicated that they were a 4-H member for 9 years $(n=12$, $38.7 \%$ ). The second largest groups indicated the same number of responses for being a $4-\mathrm{H}$ member for 7 and 8 years $(n=5,16.1 \%)$. The number of years in which respondents were a parish 4-H Junior Leadership Club member ranged from 0 to 7 years. The largest group of respondents indicated that they were not a member of their Parish $4-\mathrm{H}$ Junior Leadership Club $(n=8,25 \%)$. Results show that the two second largest groups include the same number of respondents who indicated that they were a parish 4-H Junior Leadership Club member for 4 and 5 years $(n=7,22 \%)$.

Respondents identified their highest level of education in which they completed or are currently enrolled. The largest group of the respondents $(n=18,56 \%)$ reported completion or enrollment 
in a 4-year college program. The second largest group $(n=10,31 \%)$ reported completion of a high school diploma or GED.

Participants were asked to indicate their ownership of various social media devices, in which they were able to select ownership of more than one device if applicable. The largest number of respondents $(n=29,91 \%)$ reported that they own a desktop or laptop computer. The second largest number of respondents $(n=27,84 \%)$ reported that they own a smart phone. Table 8 illustrates data regarding ownership of social media devices.

Table 1

Ownership of Social Media Devices as Reported by Louisiana 4-H Alumni that Completed the Zammit Social Media Questionnaire

\begin{tabular}{|l|c|c|}
\hline \multicolumn{1}{|c|}{ Social Media Device } & n & Percentage $^{\text {a }}$ \\
\hline Desktop or laptop computer & 29 & 91 \\
\hline Smart phone & 27 & 84 \\
\hline iPod or mp3 player & 22 & 69 \\
\hline Cell phone & 20 & 63 \\
\hline $\begin{array}{l}\text { Gaming device (such as X-bow, Play Station, } \\
\text { or Wii) }\end{array}$ & 12 & 38 \\
\hline iPad or similar tablet device & 5 & 16 \\
\hline Total & 32 respondents & \\
\hline
\end{tabular}

Note: Table 1 will not add up to $100 \%$ as respondents were able to select more than one response.

a Percentage rounded to nearest \%.

\section{Use of Social Media among 4-H Alumni}

Objective two was to describe 4-H alumni youth affiliated with the 2011 Louisiana 4-H Youth Development Program on several social media characteristics. Participants were asked to indicate the types of social media that they currently use, in which they could select more than one of the following categories: 1) Facebook; 2) Twitter; 3) Blogs; 4) Discussion Boards; 5) Text Messaging; 6) MySpace; 7) Flickr; 8) YouTube; 9) Google Circles; 10) Pinterest; 11) I do not use social media; 12) Other. The largest group of respondents indicated that they use Facebook $(n=30,94 \%)$. The second largest group indicated that they use text messaging $(n=26,81 \%)$. Table 2 illustrates the types of social media currently used by Louisiana 4-H Alumni that completed the Zammit Social Media Questionnaire.

\section{Table 2}

Types of Social Media Currently Used by Louisiana 4-H Alumni that Completed the Zammit Social Media Questionnaire

\begin{tabular}{|l|c|c|}
\hline \multicolumn{1}{|c|}{ Type of Social Media } & $\mathrm{n}$ & Percentage $^{\mathrm{a}}$ \\
\hline Facebook & 30 & 94 \\
\hline Text Messaging & 26 & 81 \\
\hline YouTube & 16 & 50 \\
\hline Twitter & 12 & 38 \\
\hline Pinterest & 12 & 38 \\
\hline Blogs & 4 & 13 \\
\hline Discussion Boards & 2 & 6 \\
\hline Google Circles & 2 & 6 \\
\hline Flickr & 1 & 3 \\
\hline Other & 1 & 3 \\
\hline
\end{tabular}




\begin{tabular}{|l|c|c|}
\hline MySpace & 0 & 0 \\
\hline I do not use social media & 0 & 0 \\
\hline Total & 32 responses & \\
\hline
\end{tabular}

Note: Table 2 will not add up to $100 \%$ as respondents were able to select more than one response.

${ }^{\text {a }}$ Percentage rounded to nearest $\%$.

The largest group of respondents indicated that they use social media 1-3 hours per day $(n=16$, $50 \%$ ), as noted in Table 3.

Table 3

Number of Hours per day spent using Social Media Reported by Louisiana 4-H Alumni that Completed the Zammit Social Media Questionnaire

\begin{tabular}{|l|c|c|}
\hline \multicolumn{1}{|c|}{ Hours per day } & $\mathrm{n}$ & Percentage $^{\mathrm{a}}$ \\
\hline I do not use social media & 0 & 0 \\
\hline Less than 1 hour per day & 5 & 16 \\
\hline 1-3 hours per day & 16 & 50 \\
\hline 4-6 hours per day & 8 & 25 \\
\hline 7-9 hours per day & 2 & 6 \\
\hline 10 or more hours per day & 1 & 3 \\
\hline Total & 32 & 100 \\
\hline
\end{tabular}

a Total rounded to $100 \%$

Our study found that the largest group of respondents indicated that they use a smart phone to access social media $(n=16,50 \%)$. The second largest group indicated that they use a personal computer (laptop, desktop) to access social media $(n=8,25 \%)$.

Table 4

Primary Source used to Access Social Media as Reported by Louisiana 4-H Alumni that Completed the Zammit Social Media Questionnaire

\begin{tabular}{|l|c|c|}
\hline \multicolumn{1}{|c|}{ Social Media Source } & $\mathrm{n}$ & Percentage $^{\mathrm{a}}$ \\
\hline Smart phone & 16 & 50 \\
\hline $\begin{array}{l}\text { Personal computer } \\
\text { (laptop, desktop) }\end{array}$ & 8 & 25 \\
\hline Cell phone & 7 & 22 \\
\hline iPad & 1 & 3 \\
\hline Tablet other than iPad & 0 & 0 \\
\hline Library or public computer & 0 & 0 \\
\hline I do not use social media & 0 & 0 \\
\hline Other & 0 & 0 \\
\hline Total & 32 & 100 \\
\hline
\end{tabular}

${ }^{\mathrm{a}}$ Total rounded to $100 \%$

The largest group of respondents indicated that they are attracted to communicating with friends through social media $(n=23,72 \%)$ (See Table 5). 
Table 5

Features that Attract 4-H Alumni to Social Media as Reported by Louisiana 4-H Alumni that Completed the Zammit Social Media Questionnaire

\begin{tabular}{|l|c|c|}
\hline \multicolumn{1}{|c|}{ Features } & $\mathrm{n}$ & Percentage $^{\text {a }}$ \\
\hline Communicating with friends & 23 & 72 \\
\hline Pictures & 19 & 59 \\
\hline Instant access to information & 15 & 47 \\
\hline Viewing others' status & 13 & 41 \\
\hline Applications for smart phones & 11 & 34 \\
\hline Sharing / posting links & 8 & 25 \\
\hline Games & 4 & 13 \\
\hline Videos & 4 & 13 \\
\hline Discussion boards & 3 & 9 \\
\hline Other & 3 & 9 \\
\hline I do not use social media & 0 & 0 \\
\hline Total & 32 responses & \\
\hline
\end{tabular}

Note: Table 5 will not add up to $100 \%$ as respondents were able to select more than one response.

${ }^{\text {a }}$ Percentages are rounded to the nearest \%.

The largest group of respondents indicated that they use social media for the purpose of communicating with family and/or friends $(n=30,94 \%)$ as shown in Table 6.

\section{Table 6}

Reported Purposes that 4-H Alumni use Social Media by Louisiana 4-H Alumni that Completed the Zammit Social Media Questionnaire

\begin{tabular}{|l|c|c|}
\hline \multicolumn{1}{|c|}{ Purposes } & $\mathrm{n}$ & Percentage $^{\text {a }}$ \\
\hline To communicate with family and/or friends & 30 & 94 \\
\hline To become updated on friends' activities & 24 & 75 \\
\hline To become updated on events & 21 & 66 \\
\hline $\begin{array}{l}\text { To find people (old friends, classmates, } \\
\text { etc.) }\end{array}$ & 21 & 66 \\
\hline For using applications for smart phones & 11 & 34 \\
\hline To meet new people & 9 & 28 \\
\hline To promote a business / organization & 7 & 22 \\
\hline For playing online games & 6 & 19 \\
\hline Other & 0 & 0 \\
\hline Total & 32 & \\
\hline
\end{tabular}

Note: Table 6 will not add up to $100 \%$ as respondents were able to select more than one response.

a Percentages are rounded to the nearest $\%$.

The largest groups of respondents with the same number of responses indicated that they send text messages to friends very often and never participate in discussion boards $(n=20,67 \%)$ as noted in Table 7. 
Table 7

Frequency of 4-H Alumni using Social Media as Reported by Louisiana 4-H Alumni that Completed the Zammit Social Media Questionnaire

\begin{tabular}{|l|c|c|c|c|c|}
\hline \multicolumn{1}{|c|}{ Activity } & Never & $\begin{array}{c}\text { Seldom } \\
(1-5 \\
\text { times per } \\
\text { week or } \\
\text { less) }\end{array}$ & $\begin{array}{c}\text { Sometimes } \\
(6-10 \\
\text { times per } \\
\text { week) }\end{array}$ & $\begin{array}{c}\text { Often } \\
(11-15 \\
\text { times per } \\
\text { week) }\end{array}$ & $\begin{array}{c}\text { Very often (more } \\
\text { than 15 times per } \\
\text { week) }\end{array}$ \\
\hline $\begin{array}{l}\text { Comment on others' } \\
\text { profiles, photos, and/or } \\
\text { videos }\end{array}$ & $22 \%$ & $22 \%$ & $38 \%$ & $3 \%$ & $16 \%$ \\
\hline "Like" pages & $16 \%$ & $34 \%$ & $28 \%$ & $16 \%$ & $6 \%$ \\
\hline $\begin{array}{l}\text { Visit pages that you } \\
\text { "like" }\end{array}$ & $34 \%$ & $31 \%$ & $16 \%$ & $9 \%$ & $9 \%$ \\
\hline Post photos or videos & $16 \%$ & $55 \%$ & $13 \%$ & $6 \%$ & $10 \%$ \\
\hline View others' photos & $6 \%$ & $16 \%$ & $55 \%$ & $10 \%$ & $13 \%$ \\
\hline View others' videos & $30 \%$ & $20 \%$ & $33 \%$ & $10 \%$ & $7 \%$ \\
\hline $\begin{array}{l}\text { Participate in a } \\
\text { discussion board }\end{array}$ & $67 \%$ & $13 \%$ & $17 \%$ & $3 \%$ & $0 \%$ \\
\hline $\begin{array}{l}\text { Play games using social } \\
\text { media }\end{array}$ & $63 \%$ & $27 \%$ & $7 \%$ & $3 \%$ & $0 \%$ \\
\hline $\begin{array}{l}\text { Send a text message to } \\
\text { a friend }\end{array}$ & $3 \%$ & $10 \%$ & $10 \%$ & $10 \%$ & $67 \%$ \\
\hline $\begin{array}{l}\text { Update your status on } \\
\text { your social media profile }\end{array}$ & $12 \%$ & $47 \%$ & $9 \%$ & $16 \%$ & $16 \%$ \\
\hline
\end{tabular}

Note: Percentage refers to percent of respondents who responded to each item. Percentages are rounded to the nearest percent.

The largest group of respondents indicated that they use text messaging continually (1-2 times per day) $(n=27,87 \%)$. 


\section{Table 8}

Frequency of 4-H Alumni using Social Media Tools as Reported by Louisiana 4-H Alumni that Completed the Zammit Social Media Questionnaire

\begin{tabular}{|l|c|c|c|c|}
\hline \multicolumn{1}{|c|}{ Social Media Tools } & Never & $\begin{array}{c}\text { Not often } \\
(1-2 \text { times } \\
\text { per month) }\end{array}$ & $\begin{array}{c}\text { Sometimes } \\
(1-2 \text { times } \\
\text { per week })\end{array}$ & $\begin{array}{c}\text { Continually (1-2 times } \\
\text { per day) }\end{array}$ \\
\hline Facebook & 3 & 2 & 2 & 25 \\
\hline Twitter & 12 & $6 \%$ & $6 \%$ & $78 \%$ \\
\hline Flickr & $48 \%$ & $12 \%$ & 2 & $32 \%$ \\
\hline YouTube & 21 & 0 & 0 & 0 \\
& $100 \%$ & $0 \%$ & $0 \%$ & $0 \%$ \\
\hline MySpace & 4 & 7 & 10 & 6 \\
& $15 \%$ & $26 \%$ & $37 \%$ & 0 \\
\hline Discussion Boards & 22 & 1 & 0 & 0 \\
& $96 \%$ & $4 \%$ & $0 \%$ & $0 \%$ \\
\hline Blogs & 18 & 3 & 3 & 3 \\
& $75 \%$ & $12 \%$ & $12 \%$ & $13 \%$ \\
\hline Google Circles & 19 & 1 & 0 & 0 \\
& $83 \%$ & $4 \%$ & $0 \%$ & $0 \%$ \\
\hline Text Messaging & 22 & 1 & 0 & 27 \\
\hline Pinterest & $96 \%$ & $4 \%$ & $0 \%$ & $37 \%$ \\
\hline & 0 & 1 & 3 & $12 \%$ \\
\hline
\end{tabular}

Note: Percentage refers to percent of respondents who responded to each item. Percentages are rounded to the nearest percent.

The largest group of respondents indicated that they feel very comfortable having a video of themselves participating in a $4-\mathrm{H}$ event posted on a $4-\mathrm{H}$ Facebook page $(n=20,65 \%)$. The second largest group of respondents indicated that they feel very comfortable posting pictures and/or videos through social media. $(n=20,62 \%)$. See Table 9. 
Table 9

Perceived Comfort in using Social Media as Reported by Louisiana 4-H Alumni that Completed the Zammit Social Media Questionnaire

\begin{tabular}{|c|c|c|c|c|c|}
\hline Activity & $\begin{array}{c}\text { Very } \\
\text { uncomfortable }\end{array}$ & $\begin{array}{c}\text { Somewhat } \\
\text { uncomfortable }\end{array}$ & $\begin{array}{l}\text { Somewhat } \\
\text { comfortable }\end{array}$ & $\begin{array}{c}\text { Very } \\
\text { comfortable }\end{array}$ & $\begin{array}{l}\text { N/A (I do not } \\
\text { do this) }\end{array}$ \\
\hline $\begin{array}{l}\text { Posting pictures } \\
\text { and/or videos }\end{array}$ & $\begin{array}{c}0 \\
0 \%\end{array}$ & $\begin{array}{c}1 \\
3 \% \\
\end{array}$ & $\begin{array}{c}5 \\
16 \% \\
\end{array}$ & $\begin{array}{c}20 \\
62 \%\end{array}$ & $\begin{array}{c}6 \\
19 \% \\
\end{array}$ \\
\hline $\begin{array}{l}\text { Commenting on your } \\
\text { own wall/profile }\end{array}$ & $\begin{array}{c}0 \\
0 \%\end{array}$ & $\begin{array}{c}2 \\
6 \% \\
\end{array}$ & $\begin{array}{c}6 \\
19 \% \\
\end{array}$ & $\begin{array}{c}15 \\
47 \% \\
\end{array}$ & $\begin{array}{c}9 \\
28 \% \\
\end{array}$ \\
\hline $\begin{array}{l}\text { Commenting on } \\
\text { someone else's } \\
\text { wall/profile }\end{array}$ & $\begin{array}{c}0 \\
0 \%\end{array}$ & $\begin{array}{c}1 \\
3 \%\end{array}$ & $\begin{array}{c}8 \\
25 \%\end{array}$ & $\begin{array}{c}17 \\
53 \%\end{array}$ & $\begin{array}{c}6 \\
19 \%\end{array}$ \\
\hline $\begin{array}{l}\text { Commenting on } \\
\text { posted pictures or } \\
\text { videos }\end{array}$ & $\begin{array}{c}0 \\
0 \%\end{array}$ & $\begin{array}{c}2 \\
6 \%\end{array}$ & $\begin{array}{c}6 \\
19 \%\end{array}$ & $\begin{array}{c}17 \\
53 \%\end{array}$ & $\begin{array}{c}7 \\
22 \%\end{array}$ \\
\hline $\begin{array}{l}\text { Having your picture } \\
\text { on a } 4-\mathrm{H} \text { Facebook } \\
\text { page }\end{array}$ & $\begin{array}{c}0 \\
0 \%\end{array}$ & $\begin{array}{c}1 \\
3 \%\end{array}$ & $\begin{array}{c}4 \\
12 \%\end{array}$ & $\begin{array}{c}19 \\
59 \%\end{array}$ & $\begin{array}{c}8 \\
25 \%\end{array}$ \\
\hline $\begin{array}{l}\text { Having a video of you } \\
\text { participating in a 4-H } \\
\text { event on a 4-H } \\
\text { Facebook page }\end{array}$ & $\begin{array}{c}0 \\
0 \%\end{array}$ & $\begin{array}{c}0 \\
0 \%\end{array}$ & $\begin{array}{c}3 \\
10 \%\end{array}$ & $\begin{array}{c}20 \\
65 \%\end{array}$ & $\begin{array}{c}8 \\
26 \%\end{array}$ \\
\hline $\begin{array}{l}\text { Interacting with your } \\
4-\mathrm{H} \text { agent through } \\
\text { social media }\end{array}$ & $\begin{array}{c}1 \\
3 \%\end{array}$ & $\begin{array}{c}1 \\
3 \%\end{array}$ & $\begin{array}{c}5 \\
16 \%\end{array}$ & $\begin{array}{c}17 \\
53 \%\end{array}$ & $\begin{array}{c}8 \\
25 \%\end{array}$ \\
\hline
\end{tabular}

Note: Percentage refers to percent of respondents who responded to each item. Percentages are rounded to the nearest percent.

Participants were asked to identify the features that they would like to see on a 4-H Facebook page. Participants responded in an open-ended format. Common responses included incorporating features such as pictures and updated events on a 4-H Facebook page.

\section{Preference of Social Media among 4-H Alumni}

Objective three was to determine how Louisiana 4-H Alumni like to use social media as measured by the Zammit Social Media Questionnaire. The two largest groups of respondents indicated that they agree with liking to communicate with their 4-H agent through social media and liking to view others' photos ( $n=15,47 \%)$. 
Table 10

Perception of How Louisiana 4-H Alumni Like Using Social Media as Reported by Louisiana 4-H Alumni that Completed the Zammit Social Media Questionnaire

\begin{tabular}{|c|c|c|c|c|c|}
\hline Activity & SD & $\mathrm{D}$ & A & SA & N/A \\
\hline $\begin{array}{l}\text { Responding to event } \\
\text { invitations on } \\
\text { Facebook }\end{array}$ & $\begin{array}{c}4 \\
12 \%\end{array}$ & $\begin{array}{c}6 \\
19 \%\end{array}$ & $\begin{array}{c}12 \\
38 \%\end{array}$ & $\begin{array}{c}6 \\
19 \%\end{array}$ & $\begin{array}{c}4 \\
12 \%\end{array}$ \\
\hline $\begin{array}{l}\text { Commenting on } \\
\text { others' photos or } \\
\text { videos }\end{array}$ & $\begin{array}{c}3 \\
10 \%\end{array}$ & $\begin{array}{c}5 \\
16 \%\end{array}$ & $\begin{array}{c}13 \\
42 \%\end{array}$ & $\begin{array}{c}7 \\
23 \%\end{array}$ & $\begin{array}{c}3 \\
10 \%\end{array}$ \\
\hline Viewing others' photos & $\begin{array}{c}1 \\
3 \% \\
\end{array}$ & $\begin{array}{r}2 \\
6 \% \\
\end{array}$ & $\begin{array}{c}15 \\
47 \% \\
\end{array}$ & $\begin{array}{c}8 \\
25 \% \\
\end{array}$ & $\begin{array}{c}6 \\
19 \% \\
\end{array}$ \\
\hline $\begin{array}{l}\text { Playing games through } \\
\text { social media }\end{array}$ & $\begin{array}{r}11 \\
38 \% \\
\end{array}$ & $\begin{array}{c}3 \\
10 \% \\
\end{array}$ & $\begin{array}{c}7 \\
24 \% \\
\end{array}$ & $\begin{array}{c}4 \\
14 \% \\
\end{array}$ & $\begin{array}{c}4 \\
14 \% \\
\end{array}$ \\
\hline $\begin{array}{l}\text { Watching posted } \\
\text { videos online }\end{array}$ & $\begin{array}{c}3 \\
9 \%\end{array}$ & $\begin{array}{c}3 \\
9 \%\end{array}$ & $\begin{array}{c}12 \\
38 \%\end{array}$ & $\begin{array}{c}9 \\
28 \%\end{array}$ & $\begin{array}{c}5 \\
16 \%\end{array}$ \\
\hline $\begin{array}{l}\text { Participating in } \\
\text { discussion boards }\end{array}$ & $\begin{array}{c}7 \\
22 \% \\
\end{array}$ & $\begin{array}{c}5 \\
16 \% \\
\end{array}$ & $\begin{array}{c}10 \\
31 \%\end{array}$ & $\begin{array}{c}3 \\
9 \% \\
\end{array}$ & $\begin{array}{c}7 \\
22 \% \\
\end{array}$ \\
\hline $\begin{array}{l}\text { Viewing 4-H updates } \\
\text { through social media }\end{array}$ & $\begin{array}{c}4 \\
13 \%\end{array}$ & $\begin{array}{c}0 \\
0 \%\end{array}$ & $\begin{array}{c}13 \\
42 \%\end{array}$ & $\begin{array}{c}11 \\
35 \%\end{array}$ & $\begin{array}{c}3 \\
10 \%\end{array}$ \\
\hline $\begin{array}{l}\text { Communicating with } \\
\text { my 4-H agent through } \\
\text { social media }\end{array}$ & $\begin{array}{c}3 \\
9 \%\end{array}$ & $\begin{array}{c}2 \\
6 \%\end{array}$ & $\begin{array}{c}15 \\
47 \%\end{array}$ & $\begin{array}{c}9 \\
28 \%\end{array}$ & $\begin{array}{c}3 \\
9 \%\end{array}$ \\
\hline $\begin{array}{l}\text { Being identified in } 4-\mathrm{H} \\
\text { photos or videos } \\
\text { posted online }\end{array}$ & $\begin{array}{c}2 \\
6 \%\end{array}$ & $\begin{array}{c}2 \\
6 \%\end{array}$ & $\begin{array}{c}10 \\
31 \%\end{array}$ & $\begin{array}{c}13 \\
41 \%\end{array}$ & $\begin{array}{c}5 \\
16 \%\end{array}$ \\
\hline
\end{tabular}

Note: Percentage refers to percent of respondents who responded to each item. Percentages are rounded to the nearest $\%$.

The respondents' preference of social media score was determined by a summation of the scores for each activity. The following scale was created by the researcher to aid in the interpretation of the responses: $1-1.75=$ strongly disagree, $1.76-2.50=$ disagree, $2.51-$ $3.25=$ agree, and $3.26-4.00=$ strongly agree. As part of the analysis, the mean and standard deviation of the response to each activity item in the Zammit Social Media Questionnaire was calculated. The item that received the highest level of agreement from respondents was "I like viewing others' photos" with a mean $3.15(\mathrm{SD}=0.73)$. 
Table 11

Description of the Level of Agreement for Use of Social Media among Louisiana 4-H Alumni that Completed the Zammit Social Media Questionnaire

\begin{tabular}{|l|c|c|c|c|}
\hline \multicolumn{1}{|c|}{ Zammit Social Media Questionnaire Items } & $\mathrm{n}$ & $\mathrm{M}^{\mathrm{a}}$ & $\mathrm{SD}$ & Category $^{\mathrm{b}}$ \\
\hline I like responding to event invitations on Facebook & 28 & 2.71 & .97 & $\mathrm{~A}$ \\
\hline I like commenting on others' photos or videos & 28 & 2.86 & .93 & $\mathrm{~A}$ \\
\hline I like viewing others' photos & 26 & 3.15 & .73 & $\mathrm{~A}$ \\
\hline I like playing games through social media & 25 & 2.16 & 1.18 & $\mathrm{D}$ \\
\hline I like watching posted videos online & 27 & 3.00 & .96 & $\mathrm{~A}$ \\
\hline I like participating in discussion boards & 25 & 2.36 & 1.04 & $\mathrm{D}$ \\
\hline I like viewing 4-H updates through social media & 28 & 3.11 & .99 & $\mathrm{~A}$ \\
\hline $\begin{array}{l}\text { I like communicating with my 4-H agent through social } \\
\text { media }\end{array}$ & 29 & 3.03 & .90 & $\mathrm{~A}$ \\
\hline I like being identified in 4-H photos or videos posted online & 28 & 3.25 & .89 & $\mathrm{~A}$ \\
\hline
\end{tabular}

Note: Mean and Standard deviation are rounded to the nearest hundredth.

${ }^{\mathrm{a}}$ Response scale: 1 = strongly disagree (SD), 2 = disagree (D), $3=$ agree (A), and $4=$ strongly agree (SA)

${ }^{\mathrm{b}}$ Interpretive scale: $1-1.75=\mathrm{SD}, 1.76-2.50=\mathrm{D}, 2.51-3.25=\mathrm{A}$, and $3.26-4.00=\mathrm{SA}$

\section{Discussions and Conclusions}

The respondents to this study were predominantly white $(77 \%)$, teenage adults (average age was $18-19$ years), female $(69 \%)$, lived in farm or rural areas (44\%), were $4-\mathrm{H}$ members for 9 years (38\%), were $4-\mathrm{H}$ Junior Leadership members for 0 years $(25 \%)$, completed or enrolled in a 4-year college program (56\%), and owned a desktop or laptop computer (91\%). In general, the demographics of this study have similarities to the appearance of the Louisiana 4-H population. According to the 2010-2011 Louisiana 4-H State Report, a majority of 4-H members are Caucasian $(57 \%)$ females $(52.9 \%)$ (Fox, 2011). Whereas the study provides valuable information about the use and preferred method of social media among Louisiana 4-H alumni, the results present a challenge. The results of this study apply to a small percentage of the Louisiana 4-H population who are 18-19 years old, white, female, enrolled in a 4-year college program, and have vested membership in the 4-H program. The results of this study may not reflect the current use of social media among 13-15 year old Louisiana 4-H members. It is recommended that this study be conducted with a more general youth population, which may be diverse with regards to the demographic variables tested in this study.

The results of the study indicated that all (100\%) of the 4-H alumni who participated in the study use some form of social media. A majority of the 4-H alumni in this study use Facebook $(94 \%)$ and text messaging $(81 \%)$, in which they use Facebook (78\%) and text messaging $(87 \%)$ at least $1-2$ times per day. Facebook (33\%) and text messaging $(72 \%)$ were also among the top two ranked preferred methods of social media. The study also shows that 4-H alumni are generally not using MySpace (0\%), Flickr (3\%), Google Circles (6\%), Discussion Boards $(6 \%)$ and Blogs (12\%). The top five social media tools that 4-H alumni are currently using are as follows: 1) Facebook (94\%); 2) Text messaging (81\%); 3) YouTube (50\%); 4) Twitter $(38 \%) ; 5)$ Pinterest (38\%). The implication of these results is that teenage youth prefer to use Facebook and text messaging to any other type of social media. Another inference is that a majority of 4-H youth are not using the Louisiana 4-H Flickr page since only one respondent (3\%) acknowledged use of Flickr. The recommendation is that this survey be administered to a more diverse population to confirm or adjust the results of the preferred method of social media 
among Louisiana 4-H youth. Another recommendation is for the Louisiana 4-H program to explain its intended use for Flickr to $4-\mathrm{H}$ youth or post pictures to a more accessible and used form of social media, such as Facebook. Louisiana 4-H agents could utilize popular social media methods, such as Facebook, text messaging, Twitter, and YouTube to capture the attention of its intended audience for promotional and educational purposes. Extension 4-H agents could make YouTube videos of educational 4-H events, such as "How to" videos for competing in contests, and post the videos to Facebook for 4-H youth and parents to view. Posting recognition videos and pictures also helps youth to feel a sense of belonging and potential members to gain an understanding of the 4-H Youth Development organization. By utilizing the social media tools that youth currently use and being proactive in using new forms of technology, 4-H agents will develop and partnership with youth by communicating with them through their preferred method of communication-social media.

The results of this study confirmed the belief that youth use social media for social interaction with friends. A majority of respondents indicated that the reason they use social media is as follows:

1) To communicate with family and/or friends (94\%);

2) To become updated on friends' activities (75\%);

3) To become updated on events (66\%); and

4) To find people (old friends, classmates, etc.) (66\%).

In addition to communicating with people, the study indicates that 4- $\mathrm{H}$ alumni also use social media to post and view pictures. When asked what attracts 4-H alumni to social media, a simple majority of respondents identified pictures (59\%). A majority of respondents also indicated that they use Facebook to post pictures (81\%) and to view pictures (72\%). Posting pictures to the $4-\mathrm{H}$ Facebook page (47\%) was one of the main responses of surveyed participants. Participants also requested to post updated and current events to the 4-H Facebook page (59\%). The recommendation is that the Louisiana 4-H Facebook page be linked to all parish 4-H Facebook pages. Another recommendation is for 4- $\mathrm{H}$ agents to begin or continue posting updated events, pictures, and recognition of $4-\mathrm{H}$ members on social media websites, especially Facebook. Since youth view using social media as a primary form of communication, 4-H agents should be proactive in communicating with youth through social media. Extension agents can be proactive by posting upcoming events and recognizing 4-H youth through posting updates, pictures, and videos to social media websites.

The results of this survey indicated a need for an accurate and reliable Louisiana 4- $\mathrm{H}$ alumni database. The most recent 4- $\mathrm{H}$ alumni database included names and e-mail addresses for 4- $\mathrm{H}$ members who received the 2011 Louisiana 4-H Senior Honor Cord Award. The recommendation is for the Louisiana 4-H program to develop an updated 4-H alumni database that includes updated contact information including the name, e-mail address, mailing address, phone numbers, and parish of 4-H membership for each 4-H alumnus. Having an updated 4-H alumni database would provide the Louisiana 4-H program an opportunity to contact 4-H alumni to be volunteers, financial contributors, and research participants. Another recommendation is for the Louisiana 4-H program to encourage 4-H members to participate in 4-H-related surveys and questionnaires. Another recommendation is for the Louisiana 4-H Program to provide staff training on the importance of inputting accurate, updated contact information into the enrollment system. Another option for obtaining current information on 4-H alumni is to create a social media platform for $4-\mathrm{H}$ alumni in addition to having email and mailing addresses for $4-\mathrm{H}$ alumni. For example, Louisiana 4-H could establish a Facebook page for 4-H alumni, in which the Facebook page administrator could send information regarding being a volunteer, donor, or 
research participant to all 4-H alumni on the site. Allowing parental access to inputting updated contact information in a 4-H enrollment system would be another possible option for collecting current data on 4-H members and 4-H alumni.

The results of this study may also be applicable to other youth development organizations. Youth are using social media at a rapid pace, so other youth organizations can use the results of this study to promote and educate youth in a way in which they receive information bestthrough social media.

\section{References}

Boyd, D. Why Youth Social Network Sites: The Role of Networked Publics in Teenage Social Life. (2008). Retrieved on November 7, 2011 from

http://www.mitpressjournals.org/doi/abs/10.1162/dmal.9780262524834.119.

Culnan, M.J., McHugh, P.J., \& Zubillaga, J.I. (2010). How Large U.S. Companies can use Twitter and other social media to gain business value. MIS Quarterly Executive, 9(4), 243-259.

Retrieved from EBSCOhost.

Dictionary.com. Retrieved from http://dictionary.reference.com.

Dillman, D.A. (2007). Mail and Internet Surveys: The Tailored Design Method (2 ${ }^{\text {nd }}$ ed.). Hobokin: John Wiley \& Sons Inc.

Extension. (March 2010). Retrieved November 9, 2011 from

http://www.nifa.usda.gov/qlinks/extension.html.

Fox, J. (2011). Louisiana 4-H Statistics 2010-2011. (State Report). Louisiana State University, Louisiana 4-H Youth and Family Development.

Fuess, L.C. (2011). An Analysis and Recommendations of the Use of Social Media within the Cooperative Extension System: Opportunities, Risks, and Barriers. (Unpublished master's thesis). Cornell University, NY.

Hair, J.F., Black, W.C., Babin, B.J., Anderson, R.E., \& Tatham, R.L. (2006). Multivariate Data Analysis (6th ed.). Upper Saddle River, NJ: Pearson Prentice Hall.

Lenhart, A., Madden, M., Macgill, A., \& Smith, A. (2007). Teens and Social Media. Pew Research Center's Internet \& American Life Project. Retrieved from http://www.pewinternet.org/Reports/2007/Teens-and-Social-Media.aspx

Louisiana 4-H: About 4-H. Retrieved on January 18, 2012 from www.Isuagcenter.com/en/4H/about $4 \mathrm{H} /$.

Merriam-Webster.com. Retrieved from http://www.merriam-webster.com/dictionary.

National 4-H Council. (2011). About 4-H. Retrieved November 9, 2011 from http://www.4-h.org/about/. 
Pew Research Center's Internet \& American Life Project. (2010). Social Media and Young Adults. Retrieved from http://www.pewinternet.org/Reports/2010/Social-Media-and-YoungAdults.aspx.

Pew Research Center's Internet \& American Life Project. (2011). Teens, kindness and cruelty on social network sites. Retrieved from http://www.pewinternet.org/Press-Releases/2011/Teensand-social-media.aspx.

Robideau, K. \& Santl, K. (April 2011). Strengthening 4-H Communications Through Technology. Retrieved December 14, 2011 from http://www1.cyfernet.org/FRConf2011/sc/2011-RobideauStrengthen.pdf.

Skelly, J. (2005). Social Marketing: Meeting the Outreach Challenges of Today. Journal of Extension, 43, 1. Retrieved from http://www.joe.org/joe/2005february/iw1.php.

(c) Copyright of Journal of Youth Development $~$ Bridging Research and Practice. Content may not be copied or emailed to multiple sites or posted to a listserv without copyright holder's express written permission. Contact Editor at: patricia.dawson@oregonstate.edu for details. However, users may print, download or email articles for individual use.

ISSN 2325-4009 (Print); ISSN 2325-4017 (Online) 
